\title{
1991 WHITE PELICAN AND \\ DOUBLE-CRESTED CORMORANT \\ NEST CENSUS IN SASKATCHEWAN
}

KEITH RONEY, Saskatchewan Museum of Natural History, 2340 Albert Street, Regina, Saskatchewan. S4P 3V7 and RAY LONGMUIR, Saskatchewan Parks and Renewable Resources, 3211 Albert Street, Regina, Saskatchewan. S4S 5W6

During the summer of 1991 the Saskatchewan Museum of Natural History and Saskatchewan Parks and Renewable Resources (SPRR) jointly conducted a census of American White Pelican and Doublecrested Cormorant colonies in the province. A total of 14 pelican and 35 cormorant colonies was censused from 6-14 June. The last time the colonies were surveyed was in 1985. ${ }^{2}$ Survey methods included flying over traditional and newly reported nesting sites and taking aerial photographs at this peak incubation period. Incubating adults were counted from the photos to determine the number of nests.

In 1991, a total of 17,459 White Pelican and 19,547 Double-crested Cormorant nests were counted (see Tables 1 and 2). This represents a decrease of 472 pelican nests $(2.6 \%)$ and an increase of 2,921 cormorant nests $(17.6 \%)$. The number of active colonies increased by one for the pelican and by nine for the cormorant. Four pelican and 15 cormorant colonies were new since the 1985 survey. However, three pelican and six cormorant colonies had been abandoned since the last survey.

All the abandoned colonies occurred in the southern part of the province. Pelicans abandoned colonies at Cypress, Basin and Lenore lakes while cormorants abandoned colonies at Cypress, Basin, Lenore, Mud, Old Wives and Reed lakes. Drought conditions and low water levels since the 1985 survey appear to be the main cause for the abandonment of all but the Cypress Lake colony. The cause for abandonment there is not readily apparent. Not only did both species abandon the nesting island at Cypress Lake, but so did the Ring-billed and California gulls. In 1969, the cormorant colony there was the largest in the province. ${ }^{3}$ Old Wives Lake dried up in 1987 and has remained virtually dry, up to and including 1991. However, even though the cormorants have abandoned this site, the pelicans continue to nest in reduced numbers. The pelican colony has declined from 2,184 nests in 1985 to 582 in 1991. In 1988, there were reported to be approximately 60 young produced at this colony ( $E$. Wiltse, SPRR, pers. comm.).

There were four new pelican colonies since the 1985 survey. These included one at Last Mountain Lake, two at Dore Lake, and one at Primrose Lake. The 15 new active cormorant colonies consisted of 1 each at Suggi, Primrose and Preston lakes, 3 at Wasekamio Lake, 4 at Last Mountain Lake and 5 at Churchill Lake. The colonies at Wasekamio were first reported in $1990 .{ }^{1}$ At that 
Table 1. 1991 NEST CENSUS OF AMERICAN WHITE PELICAN IN SASKATCHEWAN

\begin{tabular}{|c|c|c|c|c|c|c|}
\hline \multirow[t]{2}{*}{ Location } & \multirow{2}{*}{$\begin{array}{c}\text { Date } \\
\text { June } 1991\end{array}$} & \multirow{2}{*}{$\begin{array}{c}\text { Census } \\
\text { time }\end{array}$} & \multicolumn{3}{|c|}{ Pelican Nests ${ }^{a}$} & \multirow[b]{2}{*}{$\%$ change } \\
\hline & & & 1991 & 1985 & change & \\
\hline Basin Lake & 6 & 1315 & - & 227 & -227 & -100 \\
\hline Cypress Lake & 6 & 1655 & - & 90 & -90 & -100 \\
\hline Dore Lake & 11 & 1030 & $742(2)$ & - & new & - \\
\hline Iroquois Lake ${ }^{c}$ & 6 & 1345 & - & - & - & - \\
\hline Kazan Lake & 11 & 1750 & 1004 & 1145 & -141 & -12.3 \\
\hline Last Mountain Lake & 6 & 0750 & 804 & 一 & new & 一 \\
\hline Lavallee Lake & 11 & 0945 & 4890 & 4897 & -7 & n.s. \\
\hline Lenore Lake $^{b}$ & 6 & 1300 & - & 162 & -162 & -100 \\
\hline Mud Lake & 6 & 0900 & 210 & 462 & -252 & -54.5 \\
\hline Old Wives Lake & 6 & 1830 & 582 & 2184 & -1602 & -73.4 \\
\hline Preston Lake & 13 & 1330 & 70 & 157 & -87 & -55.4 \\
\hline Primrose Lake & 13 & 1900 & $5247(3)$ & $6652(2)$ & -1405 & -21.1 \\
\hline Redberry Lake & 6 & 1410 & 524 & 347 & +177 & 51.0 \\
\hline Suggi Lake & 11 & 0830 & $3386(2)$ & $1608(2)$ & +1778 & 110.6 \\
\hline Total no. nests & & & 17459 & 17931 & -472 & -2.6 \\
\hline No. of islands & & & (14) & (13) & $(+1)$ & \\
\hline Average nests/island & & & 1247 & 1379 & -132 & -9.6 \\
\hline $\begin{array}{l}\text { a Number of nesting islan } \\
\text { b Abandoned since } 1985 \\
{ }^{c} \text { Reported in } 1991 \text { that pe } \\
\text { n.s. not significant }\end{array}$ & $\begin{array}{l}\text { ds, if more thar } \\
\text { survey } \\
\text { licans were ne }\end{array}$ & $\begin{array}{l}\text { one, in pa } \\
\text { sting in } 198\end{array}$ & $\begin{array}{l}\text { entheses } \\
9\end{array}$ & & & \\
\hline
\end{tabular}

time, a cormorant colony was reported for Peter Pond Lake; however, due to higher water levels flooding the small island, the colony was not active in 1991. A pelican colony was reported to be active at Iroquois Lake in 1989 (P. Parsons, pers. comm.), but was not found in the 1991 survey.

Pelicans experienced nest declines at Kazan, Mud, Old Wives, Preston and Primrose lakes while enjoying increases at Redberry and Suggi lakes. The most significant increase was at Suggi Lake where the nest count rose from 1,608 in 1985 to 3,386 in 1991 . The Lavallee Lake colony remained stable. Aside from the abandoned colonies, cormorants increased at all colonies except at
Churchill Lake where the number of nests remained stable in spite of an increase in nesting islands from 7 to 12. The most significant nest increases occurred at Kazan $(+742)$, Last Mountain $(+1,090)$, Lavallee $(+648)$, Primrose $(+1,119)$ and Suggi $(+811)$ lakes.

In summary, the number of pelican nests remained relatively stable since the 1985 survey, experiencing only a slight decline $(2.6 \%)$. Cormorant nests increased by $17.6 \%$ since 1985. Generally, the southern colonies experienced the more significant losses due in large part to the lower water levels while the northern colonies suffered fewer losses and appear to be doing quite well. It is good to see that pelicans are 
Table 2. 1991 NEST CENSUS OF DOUBLE-CRESTED CORMORANT COLONIES IN SASKATCHEWAN

\begin{tabular}{|c|c|c|c|c|c|c|}
\hline \multirow[t]{2}{*}{ Location } & \multirow{2}{*}{$\begin{array}{c}\text { Date } \\
\text { June } 1991\end{array}$} & \multirow{2}{*}{$\begin{array}{c}\text { Census } \\
\text { time }\end{array}$} & \multicolumn{3}{|c|}{ Cormorant Nests $^{a}$} & \multirow[b]{2}{*}{$\%$ change } \\
\hline & & & 1991 & 1985 & change & \\
\hline Basin Lake & 6 & 1315 & - & 745 & -745 & -100 \\
\hline Churchill Lake & 13 & 0900 & $2506(12)$ & $2508(7)$ & -2 & n.s. \\
\hline Cypress Lake & 6 & 1655 & - & 553 & -553 & -100 \\
\hline Dore Lake & 11 & 1030 & $2497(3)$ & $2204(3)$ & +293 & 13.3 \\
\hline Kazan Lake & 11 & 1750 & 3862 & 3120 & +742 & 23.8 \\
\hline Last Mountain Lake & 6 & 0750 & $2854(7)$ & $1764(3)$ & +1090 & 61.8 \\
\hline Lavallee Lake & 11 & 0945 & 2263 & 1615 & +648 & 40.1 \\
\hline Lenore Lake $^{\mathrm{b}}$ & 6 & 1300 & - & 853 & -853 & -100 \\
\hline Mud Lake & 6 & 0900 & 一 & 26 & -26 & -100 \\
\hline Old Wives Lake & 6 & 1830 & - & 96 & -96 & -100 \\
\hline Peter Pond Lake. ${ }^{c}$ & 13 & 1000 & - & - & 一 & - \\
\hline Preston Lake & 13 & 1330 & 85 & - & new & - \\
\hline Primrose Lake & 13 & 1900 & $2336(3)$ & $1217(2)$ & +1119 & 91.9 \\
\hline Redberry Lake & 6 & 1410 & 102 & 43 & +59 & 137.2 \\
\hline Reed Lake & 6 & 1800 & - & 45 & -45 & -100 \\
\hline Suggi Lake & 11 & 0830 & $2648(3)$ & $1837(2)$ & +811 & 44.1 \\
\hline Wasekamio Lake & 13 & 1020 & $394(3)$ & 一 & new & - \\
\hline Total no. nests & & & 19547 & 16626 & +2921 & 17.6 \\
\hline No. of islands & & & (35) & (26) & $(+9)$ & \\
\hline Average nests/island & & & 558 & 639 & -81 & -12.7 \\
\hline \multicolumn{6}{|c|}{${ }^{a}$ Number of nesting islands, if more than one, in parentheses } & ${ }^{\mathrm{b}}$ Abandoned since 1985 survey \\
\hline \multicolumn{7}{|c|}{${ }^{c}$ First reported active in 1990: 30 nests } \\
\hline \multicolumn{7}{|c|}{${ }^{d}$ First reported active in 1990: 191 nests } \\
\hline
\end{tabular}

establishing themselves once again on Last Mountain Lake.

Acknowledgements We thank Dave Dalke for his capable piloting for the survey. Thanks go to Merv Syroteuk, A/Superintendent, Prince Albert National Park, and the personnel of the Department of National Defense, Medley, Alberta, for granting permission to census the colonies at Lavallee and Primrose lakes, respectively. Also we thank Kevin Callele for assisting one day with the survey.

1. JAMES, P. and K. RONEY. 1991 New Double-crested Cormorant colonies in Saskatchewan. Blue Jay 49:27.

2. RONEY, K. and M. HLADY. 1986. 1985 Census of pelican and cormorant colonies in Saskatchewan. Blue Jay 44:177-179.

3. VERMEER, K. 1970. Some aspects of the nesting of Double-crested Cormorants at Cypress Lake, Saskatchewan, in 1969: a plea for protection. Blue Jay 28:11-13. 